\title{
Wicked Traffic in Girls: Prostitution and Reform in Sioux City, 1885-1910
}

\section{William L. HeWITT}

SIOUX CITY, like other western towns with bad reputations, has long been notorious for its lawlessness. The 1947 western movie Angel and the Badman confirms that the town's reputation remained vivid after World War II. Early in that film, the hero, Quirt Evans, played by John Wayne, confronts three outlaws. When asked what would have happened if the outlaws had known his gun was not loaded, the hero replies, "There would have been Saturday night in Sioux City." In popular myth Sioux City residents condoned lawlessness. Yet even in the city's early years leading citizens had made efforts to control or eliminate vice. ${ }^{1}$

The attempt to reform the "oldest profession," for example, divided Sioux City's citizens into two broad camps. Put simply, one powerful group viewed vice as inevitable and tried to control it or even profit from it. By the 1890s, this group had gradually developed regular police procedures designed to control prostitution without eradicating it. Simultaneously, less powerful moral reformers challenged these procedures, even from within the police department itself. These moral reformers represented a spectrum of opinions: some viewed vice as social maladjustment; others regarded it as a moral outrage. Powerful

I am grateful to Sr. Mary Jane Koenigs of the Briar Cliff College Inter-Library Loan Department for making research by mail bearable.

1. Sioux City's reputation is further confirmed in The WPA Guide to 1930 s Iowa, compiled and written by the Federal Writers' Project of the Works Progress Administration for the State of Iowa (1938; reprint, Ames, 1986), 303-4.

THE ANNALS OF IOWA 51 (Fall 1991). (C)The State Historical Society of Iowa, 1991. 
economic interests in the city resisted their efforts, while many citizens offered only half-hearted support in the form of Sunday morning indignation. City officials did not so much resist their efforts as deflect them; continuing to believe that prostitution could not be eliminated, they sought to relocate it to less visible portions of the city. Thus, while reformers managed to rescue a few women from a "life of shame," they did not force basic changes in the system that supported prostitution. ${ }^{2}$

DURING THE LATE NINETEENTH CENTURY vice had increased proportionately with Sioux City's population. As the city grew, saloons, gambling dens, and houses of prostitution flourished amongst other downtown businesses. City business interests inconspicuously secured substantial income from gambling, liquor, and prostitution. As the city's white business elite became more established, they built residences on Codfish Hill, just north of the downtown business district, thus physically removing themselves from direct association with the vice that continued to thrive in the older part of downtown. The red light district-located near the railroad tracks on Jones, Pearl, Second, Third, and Fourth streets-became known as the Soudan. A Sioux City Journal reporter indicated later that "because of the large number of bad negroes in the district, 'the

2. For the historiography of prostitution, see Elliott West, "Scarlet West: The Oldest Profession in the Trans-Mississippi West," Montana: The Magazine of Western History 31 (1981), 16-27; and Anne M. Butler, "More on the Social Evil and Scholarship," Journal of the History of the Behavioral Sciences 25 (1989), 217-19. Prostitution in Sioux City was similar in many ways to prostitution in other cities, as seen in the earlier study by William W. Sanger, The History of Prostitution: Its Extent, Causes, and Effects throughout the World (New York, 1859), esp. 452, 488, 524. For a good analysis of Sanger, see Barbara Meil Hobson, Uneasy Virtue: The Politics of Prostitution and the American Reform Tradition (New York, 1987), 89-102. Other especially useful accounts of prostitution reform include Roland Richard Wagner, "Virtue against Vice: A Study of Moral Reformers and Prostitution in the Progressive Era" (Ph.D. diss., University of Wisconsin, 1970); and Ruth Rosen, The Lost Sisterhood: Prostitution in America, 1900-1918 (Baltimore, 1982), chap. 1, "From Necessary to Social Evil." Many cities created vice commissions which published their findings. Arno Press reprinted some of these in the 1970s. See, for example, Chicago's 1911 Vice Commission Report in The Social Evil in Chicago (New York, 1970), and those from Minneapolis (1911) and Philadelphia (1913) in The Prostitute and the Social Reformer: Commercial Vice in the Progressive Era (New York, 1974). 
Soudan' seemed an appropriate name for it. Not only were a large number of the denizens black, but the lives of those who lived there was [sic] as black as the night they loved so well, and their deeds were deeds of darkness." ${ }^{3}$

Despite vituperative descriptions of the Soudan from the press and pulpit, Sioux City's residents accepted vice as a natural condition for a city growing so rapidly. Sioux City was a boom town in the early 1880 s. Its population increased from 1,380 in 1868 to 19,060 in 1885 . Traffic on the Missouri River and the railroads made Sioux City an entrepôt for agricultural products and supported a growing meatpacking industry. During this boom era, Sioux Citians' pocketbooks weighed more heavily than their consciences. The town's business interests accepted prostitution and squelched every effort to eliminate it. By the mid-1890s officials had established procedures to regulate prostitution. These procedures kept down the visibility of prostitution without eliminating it and the benefits it bestowed on the town's business climate. ${ }^{4}$

3. Sioux City Journal, 10 September 1901. John F. Schmidt, A Historical Profile of Sioux City (Sioux City, 1969), 75, refers to houses of prostitution as "bed bugs" in a picture showing construction of the city's elevated railroad in the early $1890 \mathrm{~s}$. His caption is incorrect, however. He says the photograph shows Third and Jones streets; it should be Third and Virginia looking northwest. The subject of prostitution evokes popular myths among longtime residents of Sioux City. The most common myth is that Pearl Street was supposedly named after some unspecified mayor's prostitute, and was changed to Grandview due to his irate wife's urging. Some storytellers also suggest what they consider to be a less plausible story, namely, that Pearl Street was named for an African-American cook for the early riverboat crews. This latter story is repeated in S. E. Gilbert, "The History of the Negro in Sioux City from 1855 to $1900, " 1-2$, Blacks in Iowa Collection, State Historical Society of Iowa, Des Moines. The best explanation for the name change is in Scott Sorensen and Paul Chicoine, Sioux City: A Pictorial History (Norfolk, VA, 1982), 61: "Residents ... successfully petitioned the city council to rename the portion of Pearl above Ninth Street to 'Grandview Boulevard,' in an attempt to disassociate their homes from the sordid reputation of Lower Pearl Street." See also Ordinance H-6300, 4 April 1914, Pearl Street changed to Grandview Boulevard, Municipal Code of Sioux City: 1943.

4. Sioux City Journal, 10 September 1901, 2 August 1936; "Sioux City History," Local History Scrapbook, vol. 2, p. 27, Sioux City Public Library; William Silag, "City, Town, and Countryside: Northwest Iowa and the Ecology of Urbanization, 1854-1900" (Ph.D. diss., University of Iowa, 1979); idem, "A Mercantile History of Sioux City in the 1880s," Palimpsest 65 (1984), 26-32. Many studies reveal that local authorities and business groups con- 
The moral reformers' initial attempts to curb vice in the city focused on the liquor traffic. In this effort, they found valuable allies in state government. But they faced persistent local opposition until a heinous crime-the notorious murder of a prominent reformer in 1886 - gave a boost to the reform forces.

In 1882 the citizenry, believing that liquor helped lubricate the boom, overwhelmingly voted down a proposed amendment to the Iowa Constitution that would have banned intoxicating drink. ${ }^{5}$ And when the Iowa legislature enacted its strongest prohibition statute to date in 1886, the so-called Clark Bill, local saloon owners threatened to "pound" Iowa Congressman Isaac Struble for supporting the statute. They received the support of 136 local business leaders who signed a petition stating that while they did not condone the deleterious consequences of the liquor traffic on certain individuals, strict enforcement of the Clark Bill would be "extremely detrimental to the business interests of the city" at a critical stage in the city's development. "At this time," they explained, "we are laboring under a heavy burden brought on by the increased necessities of the city in its change from a thriving village to an important business center, and can ill afford to lose the revenues which may be had if the law is not enforced." An opposing petition signed by prominent Sioux City women representing "not less than 460 husbands

doned vice because they believed it helped sustain prosperity. See James R. McGovern, "Sporting Life on the Line': Prostitution in Progressive Era Pensacola," Florida Historical Quarterly 54 (1975), 133, 140; David C. Humphrey, "Prostitution and Public Policy in Austin, Texas, 1870-1915," Southwestern Historical Quarterly 86 (1983), 473-516; Neil Larry Shumsky, "Tacit Acceptance: Respectable Americans and Segregated Prostitution, 1870-1910," Journal of Social History 19 (1986), 665-79; idem, "Vice Responds to Reform, San Francisco, 1910-1914," Journal of Urban History 7 (1980), 31-47; Stephen G. Sylvester, "Avenues for Ladies Only: The Soiled Doves of East Grand Forks, 1887-1915," Minnesota History 51 (1989), 291-300.

5. Sorensen and Chicoine, Sioux City, 40. The amendment passed statewide, but was declared unconstitutional. See Dan Elbert Clark, "The History of Liquor Legislation in Iowa, 1878-1908," Iowa Journal of History and Politics 6 (1908), 503-35; Leland Sage, A History of Iowa (Ames, 1974), 203-4; Richard Jensen, The Winning of the Midwest: Social and Political Conflict, 1888-1896 (Chicago, 1971), 93-98. 
and fathers and 1,060 children" attacked the business interest for sullying "the fair name of Sioux City." 6

By that time the opponents of liquor, gambling, and prostitution had been reinforced by the arrival in October 1885 of a new pastor at Sioux City's First Methodist Episcopal Church. The new pastor, George C. Haddock, promptly assumed the role of firebrand at the head of the moral reform movement. By the following July he had galvanized other community religious leaders and reform-minded citizens to form a Law and Order League. Members of the league took it upon themselves to investigate personally suspected violations of the liquor law by saloon keepers, and Haddock assumed the roles of plaintiff and witness against them in court. ${ }^{7}$

The saloon element retaliated. On the night of August 3, 1886, an unidentified assailant gunned Haddock down after he left his horse at a livery stable. A Sioux City Journal headline the following day called the assassination "the most foul crime in the history of Sioux City." Then, in a front-page editorial the next day, editor George D. Perkins argued that the murder was the result of an impunity toward the law, "nurtured by public officers, promoted by business men in a mad rush for dollars." 8

Haddock quickly became a martyr for prohibitionists nationwide, while Sioux City residents recoiled in outrage and shock at the spread of the image of their community as a wideopen frontier town of questionable morality. Their reaction yielded quick results. Despite the provisions of Iowa law prohibiting the sale of intoxicating liquors, the 1886 Sioux City

6. Sorensen and Chicoine, Sioux City, 41 (who incorrectly date the Clark Bill to 1885 rather than 1886); Clark, "History of Liquor Legislation," 552-53; City of Sioux City Collection, vol. 158, Sioux City Public Museum; Sioux City Journal, Centennial Edition, 25 July 1954.

7. Frank C. Haddock, The Life of Rev. George C. Haddock (New York, 1887); Thomas S. Smith, "A Martyr for Prohibition: The Murder of Rev. George C. Haddock," Palimpsest 62 (1981), 186-89; Sorensen and Chicoine, Sioux City, 41, 63; "Sioux City History," Scrapbook.

8. Sioux City Journal, 4, 5, 6 August 1886; Smith, "Martyr for Prohibition," 189-93; Jane Rapp, ed., South Sioux City, 1887-1987: Where the Good Life Gets Better (South Sioux City, NE, n.d.), 11; Sorensen and Chicoine, Sioux City, 63-65; History of the Counties of Woodbury and Plymouth, Iowa (Chicago, 1890-91), 254-63; George W. Argo and W. W. Erwin, Who Killed Haddock? The Famous Arensdorf Case (Minneapolis, 1888). 
Directory had boldly listed fifty-five "saloons." The 1887 Directory listed none. ${ }^{9}$

Purveyors of liquor, gambling, and prostitution withdrew to Stanton and Covington (now South Sioux City), Nebraska, to escape the inhospitable climate in Sioux City following Haddock's murder. Typically small towns, Stanton and Covington transformed almost overnight into Sioux City's "Sin Suburbs." A Sioux City Journal reporter observed that the early morning calm in those towns, which a visitor would find "as quiet and subdued as a rural cemetery," belied their true nature. Other than gambling dens, saloons, and "resorts," he noted, "there are no improvements and little commercial activity, for the inhabitants depend on Sioux City to supply their wants." 10

Stanton and Covington thrived side by side, separated by the Fashion Theater on Bloodgood Street, offering rowdy burlesque shows where the talent was primarily epidermal and beer flowed freely between acts. These two towns, with a combined resident population of 250 persons, had fifty saloons and nearly as many bawdy houses and gambling dens. They consequently "won reputations for lawlessness and violence which equalled those of Tombstone, Deadwood and Dodge City."11

After the saloon and prostitution business moved to Covington and Stanton, a steady stream of traffic crossed the river from Sioux City "in search of excitement and forbidden pleasure." For some time a ferryboat provided the best means of transportation back and forth. When that was not available, more venturesome roisterers rowed across and back in skiffs (sometimes at considerable risk, considering their inebriated

9. Sioux City Journal, 5 August 1886; Sioux City Directory, 1886, 1887. Charles F. Hoyt, pioneer Sioux City businessman, was president of the Sioux City brewery. He included that information in public biographies before the Haddock murder, but his association with the brewery was not listed in the 1888-90 Directory, nor were any saloons or breweries listed.

10. M. M. Warner, Warner's History of Dakota County, Nebraska (Dakota City, 1893), 72-75; Rapp, South Sioux City, 12; Neil Miller, "Sioux City's 'Sin Suburbs' of the Late 80s," Local History Scrapbook, vol. 2, Sioux City Public Library; Sioux City Journal, Centennial Edition, 25 July 1954; Sioux City Journal, 26 March 1975.

11. Rapp, South Sioux City, 12-13; Local History Scrapbook, vol. 2, p. 79; Warner, Warner's History of Dakota County, 77; Miller, "Sioux City's 'Sin Suburbs.'" 


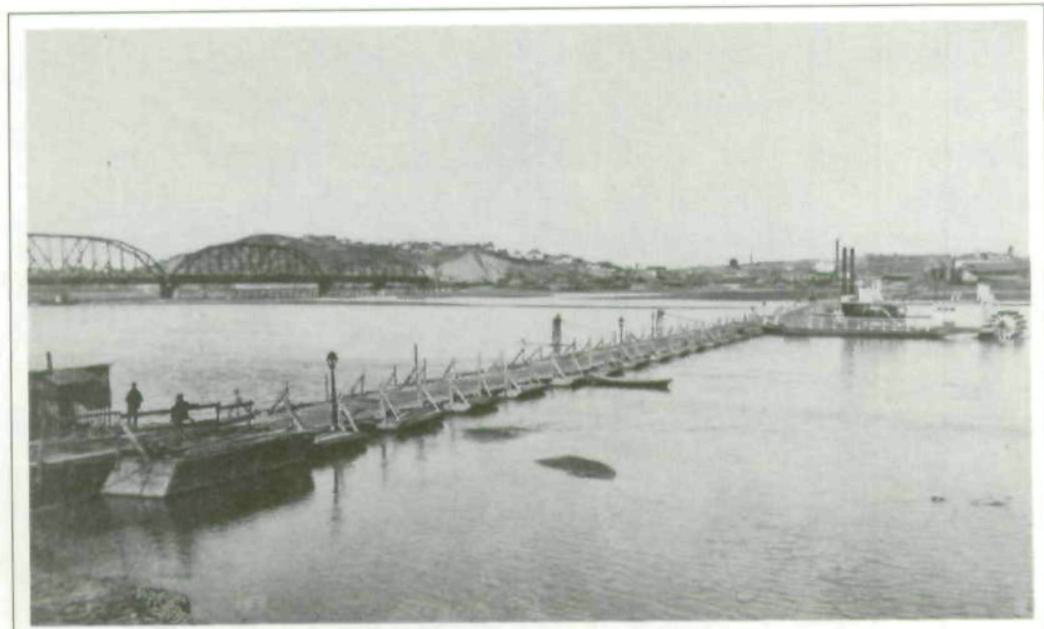

Pontoon bridge from Sioux City to Stanton, Nebraska. The newly constructed bridge in the background made the pontoon bridge unnecessary after 1896. Photo courtesy of Sioux City Public Museum.

condition). In 1889 a pontoon bridge -185 flatboats linked to one another-stretched from Iowa to Nebraska to accommodate the growing traffic in pleasure seekers. A five-cent toll for foot traffic seemed modest enough when a thirst for illegal drink or some other appetite was to be slaked. One pundit described the bridge as "a row of boats with a thirst at one end and a beer saloon at the other end."12

In May 1892 a flood destroyed the bridge, causing pleasure seekers to increase less efficient river traffic on a ferryboat named the Covington. A new bridge was ruined in another flood the following spring. In addition, three fires between January 1890 and January 1891 destroyed all of Stanton and a large portion of Covington. What remained of the two towns was incorporated into South Sioux City, Nebraska, in 1893. That town retained an interest in attracting traffic from Sioux City across the rebuilt pontoon bridge. Efforts to drive vice out of Sioux City helped to keep the Nebraska town in business. ${ }^{13}$

In 1894 Sioux City Constable Andy Johnson launched a one-man crusade against the remaining prostitution in his

12. Sorensen and Chicoine, Sioux City, 87, 89; Rapp, South Sioux City, 11-12; Schmidt, Historical Profile, 89.

13. Rapp, South Sioux City, 11-12; Schmidt, Historical Profile, 89. 
jurisdiction. He "pulled" the houses of prostitution, arresting and jailing prostitutes and madams every other night, and vowed "to drive the social evil out of Sioux City." His zeal undoubtedly won admiration from some residents, especially those who reacted to prostitution with moral outrage, but his crusade perplexed and increasingly alienated others. ${ }^{14}$

Johnson alleged that a number of businessmen had urged him to make his raids. But an investigation by a reporter for the Sioux City Journal revealed that no merchants had requested Johnson's action. On the contrary, many of them feared that his crusade would result in "the closing of the open houses ... and the scattering of the women in the rooming blocks about the city." Sioux City's regular police forces had their own fears about Johnson's crusade. The Sioux City Journal reported that the sheriff and city police opposed the arrests because they "threaten to shut off a considerable portion of the revenues of the police court." When asked about newspaper reports linking Johnson to John Maurer, one of the owners of the pontoon bridge, Chief of Police George W. Young acknowledged that he was aware of the connection between Johnson and Maurer, and he stated unequivocally, "I don't believe that Johnson is doing this on moral grounds, but I think that John Maurer has bought an interest in the pontoon bridge and has got Johnson to close up the houses for a percent of the revenue that the bridge will get by having the houses over in Covington." 15

In mid-May 1894 a grand jury investigated the allegations and implicated Johnson in taking bribes. ${ }^{16}$ Although no charges

14. Sioux City Journal, 24 April, 19, 20, 22, 28, 30 May 1894.

15. Sioux City Journal, 24 April, 5, 7, 8, 9, 10, 11 May 1894. From the beginning of Johnson's crusade there had been rumors of his collusion with Maurer. The other owners of interests in the pontoon bridge included E. C. Palmer, John M. Moan, A. L. Stetson, and William Luther. Sorensen and Chicoine, Sioux City, 109. Businessmen and city officials in most western cities in the late nineteenth century profited from prostitution without much interference. See Anne M. Butler, Daughters of Joy, Sisters of Misery: Prostitutes in the American West, 1865-1890 (Urbana, IL, 1985), 76; Roy Lubove, "The Progressives and the Prostitute," The Historian 24 (1962), 311.

16. Sioux City Journal, 12, 14 May 1894. One of Johnson's assistants had been removed from the police force earlier because he "was found in a compromising situation in Mag Olson's place on Wall street during a raid made by two of his brother officers." See Sioux City Journal, 6 May 1894. Johnson resolved to 
were brought, the allegations made during the grand jury's investigation, along with the animosity of Sioux City businessmen and officials who did not appreciate the disruption of their arrangements with the demimonde, ended Johnson's crusade. A week later, in fact, the cases against the women arrested in Johnson's raids were "dismissed for want of prosecution" because the prosecuting witnesses-including Johnsonwould not testify. ${ }^{17}$

After Johnson's crusade ended, Sioux City business and political leaders quietly allowed the return of saloons, gambling, and prostitution, yet they attempted at the same time to contain vice in the lower part of town near the railroad tracks. When criticism of the level of vice in the city began to surface again, city officials claimed to have vice under control. ${ }^{18}$

By mid-1894 the Sioux City police department and prostitutes had regularized their relationship. The common practice in Sioux City, as in other communities, was for prostitutes, madams, gambling house proprietors, and saloon keepers to pay a systematic monthly fine. Regular payment served more or less as a license, virtually ensuring the payer against arrest. Sioux City police records for 1900, for instance, include a long list of women who paid fines for "disturbing the peace," a euphemism for prostitution. A few women became local celebrities after repeated arrests. Such was the case of Mary Cake, "a notorious dive keeper of Jones Street," who found herself "in court several times, and after paying a fine has always gone back to the forbidden district." The collection of these fines became so systematic, in fact, that arrest logs in Sioux City listed prostitutes in alphabetical order. The system assured madams and prostitutes who kept their establishments free from violence, theft, and general rowdiness that they would face little interference from police. ${ }^{19}$

continue his crusade even after the grand jury "refused to assist him in carrying out its [sic] plans to rid the city of the scarlet women." Sioux City Journal, 20 May 1894.

17. Sioux City Journal, 21, 22, 30 May 1894. Only two of all the women arrested in the raids before the grand jury convened paid their fines. Sioux City Journal, 24 April 1894.

18. "Sioux City History," Scrapbook; Sioux City Journal, 26 March 1975.

19. Jail Register Book, 1 July 1898-31 May 1902, Sioux City Public Museum; 
This regular procedure for dealing with prostitution developed because it profited many people in the community. Madams and pimps took part of a prostitute's earnings for her room and board. Landlords and real estate agents also profited from allowing their buildings to be used for illicit trades. Of the twenty-one houses in which prostitutes lived in Sioux City in 1900 , for instance, only two were owned by madams; the remainder were rented from local businessmen. The police and politicians benefited from the regular collection of fines and protection money. Hotel owners, saloons, breweries, and gambling houses profited from the business brought in by prostitutes. Doctors treated prostitutes because of the constant problem of venereal diseases. Druggists benefited from the sale of drugs, both medical and recreational, to prostitutes. ${ }^{20}$

The only person who did not seem to profit a great deal from the profession was the prostitute herself. Pimps and madams undoubtedly took most of her money. A prostitute's fee depended on how well she could separate a customer from his money. Many prostitutes resorted to petty thievery to improve their incomes. Patrons of the Warwick Hotel, for

Sioux City Journal, 25 May, 12 August 1894, 31 December 1901, 16 January 1902. The Journal reported that Mary Cake was one of "a bunch of painted, dissipated women from the Soudan district [who] were arraigned .... on a charge of disturbing the peace." Judge Robert $\mathrm{H}$. Munger fined more than a dozen from $\$ 10$ to $\$ 25$ each. At the same time that official dealings with prostitution became regularized, Iowa's notorious Mulct Law of 1894 established a statewide basis in law for similar treatment for saloons. See Clark, "Liquor Legislation," 596-601. Leland Sage, History of Iowa, 204, summarizes the law as "a curious law under which a saloonkeeper could be fined $\$ 600$ or more, if local officials so decreed, for operating a saloon which had been approved by a local option election! This strange law was upheld by the State Supreme Court and somehow served to keep the traffic in liquor at a minimum, which pleased nearly everyone." Brothels had long been ignored by Sioux City police officers, even though they were the most visible and easiest form of prostitution to eliminate. They eventually came under so-called injunction and abatement laws, the first of which was passed in Iowa in 1909. These laws enabled any taxpayer to institute action against those people who maintained and owned houses of prostitution in their county. See Vern Bullough and Bonnie Bullough, Women and Prostitution: A Social History (Buffalo, NY, 1987), 283-84.

20. Twelfth Census of the U.S., 1900. See also Ruth Rosen, Lost Sisterhood, 77-78; Priscilla Wegars, "'Inmates of Body Houses': Prostitution in Moscow, Idaho, 1885-1910," Idaho Yesterdays 33 (1989), 27. 
instance, frequently had money stolen. Yet victims of crime seldom complained to the police because they did not want their names in the newspapers. ${ }^{21}$

City officials exerted considerable control over local vice activities, using the threat of arrest to keep resorts from allowing "inmates" and customers to get too rowdy. In addition to the threat of arrest, public officials generally patrolled the district to make sure that local activities were tolerable and not too visible. Infrequent sweeps seemed to mollify public concern about vice, except when an unusual disturbance in the Soudan provoked a call for reform, or the local ministry roused public ire against vice.

THE ARRANGEMENT between the demimonde and city officials worked efficiently, but it seemed to flout the law. As a result, shortly after the turn of the century, the press and reformers who were repulsed by the presence of prostitution in their community exerted increasing pressure on public officials, who responded reluctantly. They remained skeptical that prostitution could be eliminated, but gradually, as the visibility of vice interfered with the expansion of the downtown business district, they forced houses of prostitution to relocate to less visible portions of the city.

After President William McKinley's assassination on September 6, 1901, Sioux City residents became newly preoccupied with law and order. Because McKinley's assassin, Leon F. Czolgosz, was an avowed anarchist, citizens of Sioux City, like American citizens elsewhere, feared that anarchist forces were emerging from the depths of society to infiltrate their communities. The Sioux City Journal, reflecting the fears of its readers, identified the source of those forces in their midst.

Now as a risen black ghost of the old district has come a new Soudan, greater and even worse than the old one. It is frequented by the vicious negroes, low white prostitutes, thieves, thugs, 'hop' fiends and criminals of all classes.... Among these

21. Sioux City Journal, 10 September, 1 November 1901. 
are the worst kind of degenerates. They are anarchists. They defy the laws, but nevertheless are the greatest cowards. ${ }^{22}$

Sioux City's moral reformers insisted on the eradication of this source of evil, because crime unchecked could lead to anarchy. Thus, less than ten days after McKinley's assassination, law-and-order advocates and moral reformers launched a crusade against the Soudan. On September 15, 1901, a small group of concerned citizens convened in the Peavey Grand Opera House. Banker Wilbur P. Manley, who presided at the meeting, railed against "an epidemic of crime" in the city. In his estimation, "the Soudan is the place where this crime is chiefly bred." Dean Cornell, of St. Thomas Episcopal Church, referred to the assassination of President McKinley as evidence that freedom had degenerated into anarchy, which the Soudan exemplified. Attorney E. E. Lewis concluded that McKinley was killed "by the hand of an element of anarchy that was bred in city districts such as that in this city called the Soudan." The group concluded that the Soudan must "be wiped off Sioux City's map, and wiped off right away." ${ }^{23}$

Even as they expressed their indignation toward the Soudan, these moral reformers did not allow the economic underpinnings of prostitution to go unchallenged. Attorney Prince Albert Sawyer, disturbed by the small turnout for the gathering, complained that "commercialism" caused businessmen to "subordinate to it the principles of honor and manhood." He told his fellow moral reformers that "those who go about to get support to a moral movement are met with declination from these men because the persons engaged in lawlessness are their patrons." He suggested the enforcement of the penal code, which provided for a three-hundred-dollar fine and imprisonment in the county jail not to exceed six months for anyone who leased property "knowing that the lessee intends to use it as a place or resort for the purpose of prostitution and lewdness." By thus alienating the landlords, Sawyer

22. Ibid., 10 September 1901.

23. Ibid., 16 September 1901. 
inadvertently ensured that the reform effort would receive limited support. ${ }^{24}$

Despite resistance from some business leaders, however, antiprostitution forces mobilized to end the lawlessness in the Soudan. In fact, the movement was spearheaded by merchants who had establishments near the red light district but who did not profit from prostitution. They waged war on the Soudan by aiming at the heart of the district, the Warwick Hotel. John Reese, an operator of a cigar and news stand north of the Warwick, commented that the prostitutes "solicit people right in front of my store, and they come in here and hang around until I have to drive them out. The police certainly know about it, for they go past there time and again." 25

The Warwick Hotel was owned by J. Locke Warwick, who came to the city "without much except his nerve and money making ability." His Horatio Alger-like entrepreneurial success should have earned him the respect of Sioux City's leading citizens, except that he was African-American and his fortune relied too conspicuously on profits from vice. According to $\mathrm{Mr}$. Ball, the proprietor of Hotel Ball, which was located near the Warwick but did not allow "persons of bad character and no Indians nor negroes,"

It [the Warwick] has lost me hundreds of dollar's [sic] worth of business. Those white and colored women parade up and down in front of my hotel and entice men into their house and rob them. They make indecent exposures of their persons inside and outside of the house. They begin about midnight every night and make things hideous with their fighting, quarreling and noisiness. ${ }^{26}$

The campaign against the Warwick capitalized on the prejudices of Sioux City's white citizens, who easily associated vice with the black community, as the name they gave to the crimeridden district implies. City officials and the local press assiduously raised the visibility of black prostitutes by arresting them

24. Ibid.

25. Ibid., 1 November 1901.

26. Ibid. 
more often and reporting their cases in police court more sensationally. Thus, by early 1902, the moral reformers, in alliance with business leaders who did not profit from prostitution, had succeeded in closing the Warwick. ${ }^{27}$

Meanwhile, the more numerous houses of prostitution operated by whites continued to do business uninhibited on the east side of downtown near the South Bottoms. In March 1902 a group of citizens responded to ministerial appeals for a city government free from corruption and committed to eradicating vice. This group of moral reformers, seeking the elimination of prostitution, demanded more than perfunctory attempts to regulate prostitution. According to spokesperson Dr. F. E. Day, the city's government should, at the very least, have been "organized as a positive force for the suppression of vice, and ... private citizenship should not be required to force the police department to spasmodic exhibitions of activity." But it took more than the protests of reformers to spur city officials to act. ${ }^{28}$

City officials finally acted to curb violence, which continued in the downtown district even in the absence of the Warwick. On November 21, 1902, Joe Burke, a packinghouse worker in a drunken state, seriously wounded two men with a revolver at Sophia Lee's, a resort on Jones Street named for a notorious madam. The shooting, a reporter speculated in the Sioux City Journal, "may result in the closing up of all the dives in that locality and possibly Pearl Street." An earlier administration had removed "the blot of the 'Soudan'" from Third and Jones Streets. Now, "the mayor and the chief of police are seriously considering the advisability of not only closing up the Jones street resorts, but of transporting the Pearl street houses to a more retired portion of the city." 29

City officials had concluded that vice could not be totally eliminated, so they sought to remove vice from the downtown business district without provoking additional protests from another constituency in town. Thus, Mayor Ernest W. Caldwell

27. Sioux City Journal, 1 November 1901. The 1902 Sioux City Directory does not list the Warwick Hotel. Wagner, "Virtue against Vice," 80, also found that black prostitutes were arrested more often.

28. Ibid., 1, 2, March 1902.

29. Sioux City Journal, 21, 24 November 1902. 
publicly supported the closing of the resorts, but at the same time he sanctioned the relocation of the displaced prostitutes to a predominantly black neighborhood on the city's west side. According to Mayor Caldwell, the houses were located "in the heart of the business portion of the city" and should be moved to "some spot where vice would not be flaunted in the face of everybody." Chief of Police William C. Davenport agreed with the mayor and offered an explicit rationale for the city's policy of regulation rather than extermination of prostitution.

Universal experience has demonstrated that this form of vice cannot be blotted out, and therefore it must be controlled. It would not do to scatter women of this character all over the city. If they could be located in some retired quarter of the city, where the motives of those who went there could not be misinterpreted and where the sensibilities of decent people would not be shocked it would be a good thing.

Because, in Davenport's estimation, this form of vice could not be eliminated, he sought the community's suggestions-more likely its sanction-for a suitable, less conspicuous place to relocate and segregate "women of this character." The west side, where African-Americans increasingly lived as informal Jim Crow arrangements took hold in the city, seemed the best locale for prostitution. This conclusion seemed natural to Sioux City's white residents, who had already come to associate vice with the black community. ${ }^{30}$

The resolve to relocate the vice district to the west side was reinforced by the construction of a new hotel on the northwest corner of Third and Nebraska streets in the same year. The new construction would supposedly eradicate the vice district. In fact, most of the houses that had formerly occupied the area had already been moved surreptitiously. Thus the notorious Soudan district, which had earlier adjusted to numerous police administrations, disappeared as an entity for localized prostitution in the wake of urban renewal. For the time being, African-

30. Ibid., 24 November 1902. On the increasingly rigid Jim Crow arrangements in Sioux City in the early twentieth century, see William L. Hewitt, "So Few Undesirables: Race, Residence, and Occupation in Sioux City, 18901925," Annals of Iowa 50 (Fall 1989/Winter 1990), 158-79. 
American prostitution had moved to the west side of town, and city officials maintained control of prostitution there and downtown at the east end of Fourth Street near the South Bottoms. $^{31}$

As the downtown business district continued to expand, however, city officials once again came under pressure to eliminate the remaining houses of prostitution on Pearl Street. In July 1905 Mayor William G. Sears announced that Pearl Street was "becoming too much of a business center, too much of a publicly traveled street, to allow the houses to remain there.... They must go from there, as they had from Jones street, swept away by the advance of business and trade." Thus city officials once again responded to public pressure to reduce the visibility of prostitution in their city. But the Sioux City Journal reported that the most recent campaign merely forced "denizens" to work out of rooming houses in "more respectable sections of the city." Mayor Sears feared that these "rooming houses" would not maintain their "alleged respectability" for long. He also reiterated one of the long-standing economic problems that contributed to the continued existence of prostitution. "The greatest trouble we have in this matter," he argued, "is the rapacity of property owners. Many of them have these people for tenants and they obtain many times the rental for their houses that they would obtain for more legitimate enterprises." 32

Urban renewal again threatened the remaining downtown resorts in 1908, as reformers renewed their attacks on the purveyors of vice on the perimeter of the expanded business district. For example, businessman Charles J. Zeman notified the prostitutes of Ona Edwards's resort, which occupied the second floor of his property on the northwest corner of Third and Pearl streets, that they must vacate the premises. He indicated that he had grown "tired of this everlasting trouble in court" because of

31. Sioux City Journal, 14 March 1902; Hewitt, "So Few Undesirables," 168, 170. See also Wagner, "Virtue against Vice," 264; James Wunsch, "Prostitution and Public Policy: From Regulation to Suppression, 1858-1920" (Ph.D. diss., University of Chicago, 1976), 159.

32. Sioux City Journal, 28 September 1905. 


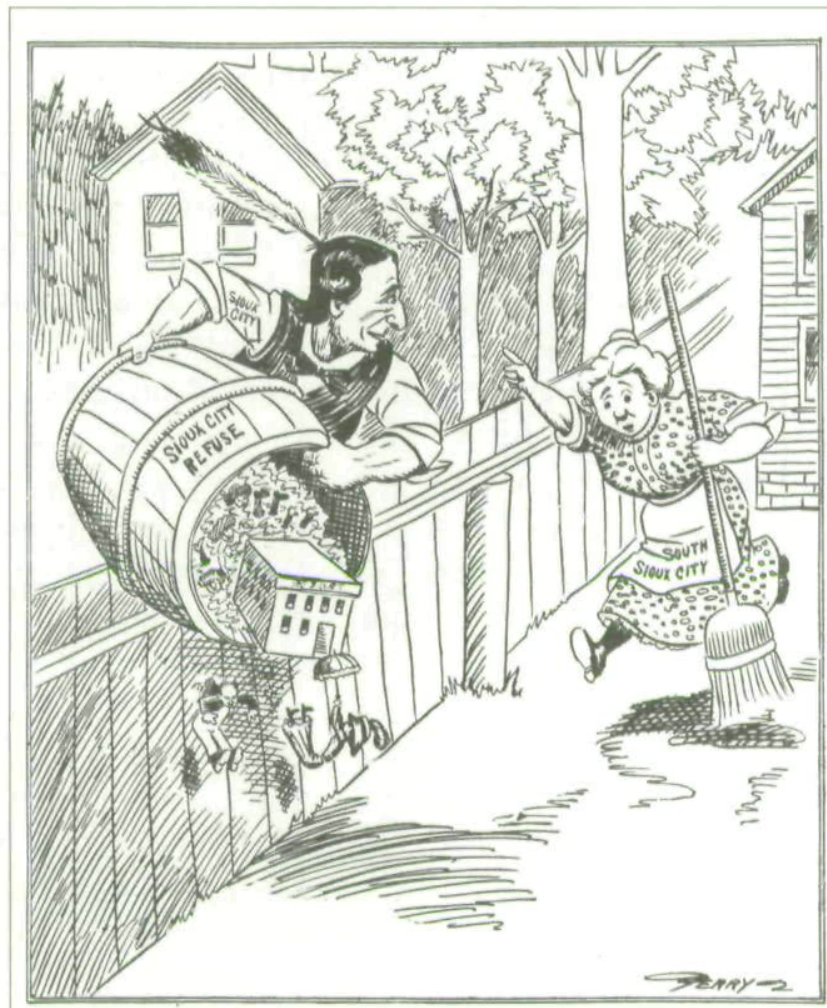

"A Protest," from Sioux City Journal, May 19, 1909.

the injunctions he received as owner of a house of prostitution. More important, he planned a new hotel for the site. ${ }^{33}$

As displaced prostitutes scurried to find new residences in the aftermath of the expansion of the business district, some people feared that they would again set up operations in South Sioux City. ${ }^{34}$ But prostitution remained a money-making business for many people in Sioux City, if not for the women themselves. The city responded to moral reformers only when extreme violence occurred, as in the cases of the Haddock murder or the assassination of William McKinley, or when moral reform coincided with the interests of the city's business leaders.

33. Ibid., 6 November 1908.

34. Ibid., 19 May 1909. 
THOSE MORAL REFORMERS who sought to eradicate prostitution as a blight on the community and a threat to its security succeeded only in securing the profession's relocation to less visible portions of the city. Meanwhile, another reform effort took a different tack: to eradicate prostitution by rescuing the wayward girls who were the "inmates" of the houses of ill repute. These moral reformers believed that if the prostitute could be redeemed from her trade, vice would be eliminated at the source. Clergy, lawyers, owners of small businesses, and especially wives of prominent business leaders provided the leadership for this movement. ${ }^{35}$

As early as February 1894, prominent Sioux City women had maintained a home for "friendless women" at 3201 Jennings Street. In 1896 the Women's Home Association aided forty-three adults and fourteen infants. The home was intended as a way station for women with no prospects and sometimes with children to care for. It was feared that these women might resort to criminal behavior to better their lot, if they had not already done so. "From the first," the secretary reported, "it has been the desire of the association to keep young and unskilled girls until they become perfectly qualified for all kinds of domestic labor, and are thoroughly grounded in honest and upright principles of life and Christian character." As with other institutions established in the late nineteenth century for the reform of girls and young women, white, middle-class domesticity provided the ideal. ${ }^{36}$

The women these reformers sought to rescue from prostitution were predominantly young, mostly American-born white women with few employment alternatives. ${ }^{37}$ Sixty-two

35. The eighteen reformers identified in newspaper articles at this time included among their occupations one banker, three merchants, four ministers, and seven lawyers. Compare David Danbom, "The World of Hope": Progressives and the Struggle for an Ethical Public Life (Philadelphia, 1987), 82, 119.

36. Sioux City Journal, 12 January 1896, 26 November 1901. The Girls Reform School of Iowa was based on a similar ideal. See Douglas Wertsch, "Iowa's Daughters: The First Thirty Years of the Girls Reform School of Iowa, 1869-1899," Annals of Iowa 49 (1987), 77-100.

37. The arrest logs for the Sioux City Police Department from 1898 to 1902 indicate 107 arrests for prostitution. Of the 76 for whom occupations are listed, 32 were domestics, 7 were housekeepers, 8 were seamstresses, and 4 
percent of the prostitutes identified in the 1900 U.S. Census were under age twenty-five. Only 25 percent were foreignborn, even though more than 35 percent of Sioux City's total population was foreign-born. At a time when less than one percent of Sioux City's total population was African-American, 13 percent of its prostitutes were African-Americans who worked in two segregated houses of prostitution. Eleven percent were married; another 9 percent were widowed or divorced. Unplanned or unwanted children were not uncommon, and many daughters, scorned by society at large, followed in their mothers' footsteps. For example, Eva, age nineteen, worked with her mother, Hattie Lindsay, in her house of prostitution at $303^{1 / 2}$ Jones Street. ${ }^{38}$

The prostitutes worked in a variety of situations. A brothel "inmate" worked for a madam and enjoyed more security in the profession than a street walker. In 1900 Sioux City had seventeen major houses of prostitution in the Soudan. The number of prostitutes working in a house ranged from three to thirteen, with seven being the average. Women also worked out of saloons and dance halls. Some women worked in "cribs" small, flimsy shacks increasingly located on the west side of town, where city leaders were increasingly attempting to con-

\footnotetext{
were dressmakers. Jail Register Book, 1 July 1898-31 May 1902, Sioux City Public Museum. The historiography of the "social evil" has traditionally portrayed prostitutes as victims and harlots. By the second decade of the twentieth century, analysts were concluding that lack of employment opportunity drove many working-class women into prostitution. See "Social Evil in a Smaller City," The Survey 25 (6 May 1911), 212. "As much as anything it was cruel economic exploitation then prevalent that brought young girls and women to prostitution," according to David J. Leab, "Women and the Mann Act," Amerikastuclien 21 (1976), 62. Recent scholarship, however, treats prostitutes as working-class women pursuing one of the few economic choices available to them. See Butler, Daughters of Joy, Sisters of Misery; Mark Thomas Connelly, The Response to Prostitution in the Progressive Era (Chapel Hill, NC, 1980); Marion S. Goldman, Gold Diggers and Silver Miners: Prostitution and Life on the Comstock Lode (Ann Arbor, MI, 1981); Hobson, Uneasy Virtue; Paula Petrik, No Step Backward: Women and Family on the Rocky Mountain Mining Frontier, Helena, Montana, 1865-1900 (Helena, MT, 1987); David J. Pivar, Purity Crusade: Sexual Morality and Social Control, 1868-1900 (Westport, CT, 1973); Rosen, Lost Sisterhood; and Wagner, "Virtue against Vice."

38. Twelfth Census of the U.S., 1900; "Sioux City History," Scrapbook.
} 
fine the black population and vice. A reporter offered a description in 1901 of a typical "den."

A look into one of these dens is revolting. Two or three gayly, but cheaply, furnished rooms constitute a resort.... For the entertainment of those who drop in, women bedecked with powder, carmine, cheap jewelry and imitation dresses "sing" songs. Most of them are under the influence of liquor, and in their nicotine stained hands hold cigarettes which seem very dear to them. The rooms reek with the aroma of sour beer and tobacco smoke, disturbed only by profanity.... The women dance and curse their luck. They cease only when worn out, and then lie down to recuperate for another day's revelry, if in the course of the night the police do not lock them up and extract from them a bit of money in payment of a fine for their wickedness. ${ }^{39}$

Such a life provided the prostitute with few amenities and abysmal working conditions. Yet efforts to "rescue" these women proceeded against great odds. Moral reformers in Sioux City worked with limited resources and got little recognition for their efforts until a city official, police matron Johanna A. Thurston, became a spokesperson for their cause. Thurston had the respect of these moral reformers because of her supervision of incarcerated prostitutes. They also recognized her achievements as a social worker for homeless and abused children. ${ }^{40}$

Thurston's personal experience with prostitutes and troubled families provided her with the expertise to analyze prostitution and propose a course of action to eliminate it. In a speech delivered at a meeting of the Western Police Matrons' Association in Kansas City in 1902, she enumerated the reasons women became prostitutes: "the low dance, evil companions, stories of ease and luxury enjoyed by those living in sin, false promises of evil minded men, ill treatment at home, low wages and ignorance of other ways to earn a comfortable living." She rebuked "good women who idly look on without extending help and hope to the worst who have fallen." She believed that

39. Twelfth Census of the U.S., 1900; Sioux City Journal, 10 September 1901. 40. Sioux City Journal, 22 December 1901, 12 September 1894, 3 March 1907; Police Officers' Register, SC-38, vol. 76, pp. 38, 52, 55, 145, 201, Sioux City Public Museum. 
"good women" treated prostitutes with contempt and neglect because "when a girl has taken a misstep all her sex feel that they are brought into reproach, but this is no justification of neglect of the abused and sad, even though they may be in the lowest depths of filth and degradation." 41

In Matron Thurston's estimation, Sioux City had not succeeded in eliminating prostitution because Sioux City women had relied on the business leaders of the community to solve the problem. She illustrated her point with a parable about a woman who lost a diamond in the gutter by the side of the road and asked a man to retrieve it. He made a half-hearted effort and failed, so the "elegantly dressed" woman "took off her glove and pushed back her silks, ruffles and laces and plunged her hand into the filth and dirty water and soon brought up the bright diamond. This woman did what the man failed to do." ${ }^{42}$

Thurston proposed a solution based on the domestic ideal of the Women's Home Association. She called for direct action by "good women," who would rescue girls by taking them into their homes, where the girls could have "a pleasant home life" while they learned "all kinds of housework, laundry work, dressmaking and fancy work." This proposal reflected Thurston's goal to equip the young women with the domestic skills that would make them more desirable marriage partners, and thus remove them from prostitution. Her scheme to regenerate prostitutes got little support, however, either from the "good women" who were to take former prostitutes into their homes or from former prostitutes faced with such a domestic regimen. ${ }^{43}$

Rather than adopting such a personal approach, Sioux City reformers attempted to revitalize an institutional solution to the problem. Two months before Matron Thurston gave her speech a group of women "prominent in charitable and humanitarian work" in Sioux City had offered a proposition to the city to use the Shipman House (formerly the police station) as a refuge for fallen women. There, according to the reformers, women who had taken their "first steps toward a life of sin may be protected

41. Sioux City Journal, 21 March 1902.

42. Ibid.

43. Ibid. 
and assisted to reform." The young women would have the opportunity to "learn some means of earning a living honestly." City officials, however, refused to budget the one hundred dollars per month necessary to maintain the building. ${ }^{44}$

On the verge of failure, the reformers sidestepped obstinate city leaders in March 1903, when two Sisters of the Good Shepherd established a refuge for fallen white women at St. Joseph's Hospital. The sisters worked with the police matron to identify those women who wanted to escape prostitution. Once housed in the refuge, however, they were not free of enticements to return to their old life. The sisters reported that at night men "of low degree" whistled and called the names of women in the refuge, hoping to "entice the penitent women away from the home back to the brothels of the 'city of aching hearts.'" The women in the refuge undoubtedly worked at tasks that would develop domestic skills similar to those suggested by Matron Thurston, but the refuge supported itself with a laundry business. The harsh working conditions in a large-scale laundry business did little to prepare women for rewarding employment. ${ }^{45}$

An even narrower range of employment options was available to African-American women. To redress the white reformers' neglect of black women, Rev. J. W. Jeffress of Mount Zion Baptist Church called for "a refuge for unfortunate colored women." Jeffress had no funds, however, so as an interim step he established an employment agency in his study in the rear of the church, where he hoped "to find good positions for negro men and women who may be out of employment." Because African-American women had even fewer employment opportunities than white women, Jeffress had even less success than white moral reformers. ${ }^{46}$

44. Ibid., 29 January 1902.

45. Ibid., 23 March 1903; Sisters of Good Shepherd clipping file, Diocese of Sioux City.

46. Sioux City Journal, 24 August 1902. I have inferred that the low occupational status of African-American males also applied to African-American females. See Hewitt, "So Few Undesirables," 176. Mabel Conklin observed in a lecture on "The Double Standard" at the Mayflower Congregational Church that "it is impossible for the women [of Sioux City] to earn an honest living on such low wages as they are paid." Sioux City Journal, 30 March 1905. 
As city officials forced prostitution from downtown resorts to rooming houses in other parts of the city, while efforts to rescue women from prostitution had, at best, limited success, Matron Thurston redoubled her efforts to keep women from entering prostitution. She may also have been responding to the white slavery scare that spread as early twentieth-century moral reformers focused on that aspect of prostitution. Thurston revealed that a "wicked traffic in girls" existed between Sioux City and river cities to the south such as Omaha and Kansas City. She tried to rescue a fifteen-year-old girl from Omaha, only to be told by the girl's mother that "her daughter was where she wanted to be-in a place where she could make money." Thurston succeeded in thwarting a "traffic in young women" when she uncovered a plot to entice Sioux City girls for prostitution in St. Louis by promising them careers on the vaudeville stage. In 1906 she inveighed against a "traffic in Jewish girls," and in 1907 the local office of the Deputy United States Marshal exposed a "traffic in French girls." ${ }^{\text {"4 }}$

When "wine rooms" became the popular setting for procuring prostitutes in 1907, Thurston again attacked the purveyors of vice. She made a Saturday night tour of the vice district, storming unannounced into dance halls, the penny arcade-to view suspected obscene pictures-and saloons with wine rooms. She reported her findings to the City Federation of Women's Clubs. When apprised of the existence of the wine rooms and "the pictures ... of the sort which will poison the minds of the little folks" in the arcade, Mayor Sears denied knowing about them. Chief of Police John Dineen "hemmed

47. Ibid., 18 December 1903, 10 March 1904, 14 July 1906, 31 January 1907, 5, 28 April, 10 May 1908. Lurid literature about white slavery helped reformers who wanted to end prostitution by rescuing prostitutes. See Mary de Young, "Help, I'm Being Held Captive! The White Slave Fairy Tale of the Progressive Era," Journal of American Culture 6 (1983), 96-99. For an example of this genre of story, see John B. Hammond, "The White Slave: Great White Slave Crime," State Historical Society of Iowa, Des Moines. One historian of white slavery concludes that the American public became increasingly "anguished and excited between 1900 and 1917" about the concept of women forced involuntarily into prostitution. See Leab, "Women and the Mann Act," 55-56. 


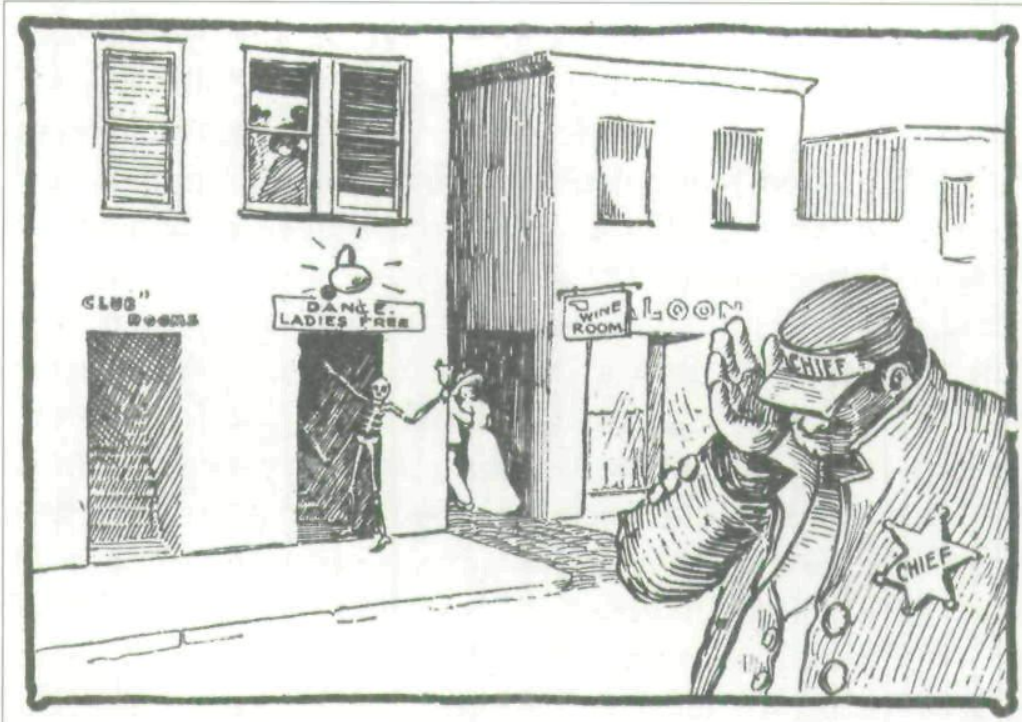

"Wine Rooms? How Could Chief Dineen Know About Them?" from Sioux City Journal, March 2, 1907.

and hawed a little, and said he did not know just what was meant by wine rooms." 48

These protestations of ignorance were sadly typical. Police Chief Dineen referred queries about vice in Sioux City to Matron Thurston, hoping to put her in the awkward position of having to explain the prominence of vice in the city that she, too, represented. Her exposés, nonetheless, alienated her from the rest of the city's officials. The next city election offered her a glimmer of hope if she could help install officials more sympathetic to her attack on business as usual. At the same time, her participation in opposition politics opened her to the continued hostility of her colleagues and the risk of losing her position. Despite her revelations, however, Mayor Sears narrowly won reelection on March 31, 1908, and he reappointed Dineen as chief of police. The day after Sears's reelection, Thurston announced her retirement as police matron, although she maintained that the outcome of the election had nothing to do with her decision. After fifteen years of service, she left a legacy

48. Ibid., 2, 26 February, 2 March 1907. 
of attempted moral reform, but prostitution flourished in Sioux City as never before. ${ }^{49}$

REFORMS intended to control or eliminate prostitution in Sioux City did not achieve their goals, but they did visibly change the nature of prostitution in the city. Proponents of controlled vice-from Constable Andy Johnson's opponents in 1894 to Mayor Sears and Police Chief Dineen at the end of the following decade-had voiced concern that closing the resorts would drive prostitution into "respectable neighborhoods." Whether intentionally or not, the proponents of regulation undoubtedly reflected the fears of many city residents, and they used those fears to support their position condoning regulated prostitution. The closing of some of the midtown resorts did, in fact, increase the incidence of street walking. In February 1907, for instance, Police Chief Dineen responded to complaints of the increasing numbers and boldness of "the street walking evil in Fifth street." But many houses of prostitution survived. At a regular meeting of the local ministerial association in 1909, Rev. J. K. Ballou, pastor of the First Christian Church, reported the comments of a visiting friend. According to Ballou, his friend, seeking lodging, had "visited a number of places marked 'Rooms to Rent' and found them to be nothing less than houses of prostitution. Some of these places are located within a stone's throw of the downtown churches, too." Ballou concluded that "the entire city seems to be honeycombed with vice and there appears to be no attempt to control it." ${ }^{50}$

Both groups of reformers - those who sought to regulate prostitution and those who wanted to eliminate it-faced the vexing problem of what to do with the prostitutes their reforms displaced. A third group-those who hoped to reform Sioux City's ills by reforming individual sinners-vainly sought the elimination of prostitution by integrating former prostitutes into middle-class domesticity. The effort to rescue women from prostitution was stillborn, however, because most women entered prostitution due to the lack of employment opportuni-

49. Ibid., 1 April 1908.

50. Ibid., 23 February 1907, 9 March 1909. 
ties available to women. That was a problem the moral reformers recognized, but could not change. Women became prostitutes in the hope of making a living, only to find that they were not better off economically in this profession. Still, they were not attracted to a life of middle-class domesticity, so most remained in prostitution, even though their profession was characterized by violence, abuse, deceit, and social ostracism. ${ }^{51}$

In contrast to the idealism of those who sought to rescue women from prostitution, the proponents of regulating prostitution affected a tone of realism and toughness as they destroyed the Soudan and removed houses of prostitution from the central business district. They relocated the red light districts in the African-American community on the west side of town, and left it near the working-class housing for meatpacking plant workers in the South Bottoms. Those locations, city officials believed, would be where their constituencies would most expect to find vice and thus would most likely tolerate it. The regulators of prostitution achieved their goal of reducing the visibility of prostitution, but the "wicked traffic in girls" continued, and the demimonde remained in "the city of aching hearts."

51. A report in the Sioux City Journal, 19 October 1902, indirectly confirmed that working women found limited opportunities in low-paying jobs. It indicated that "about 1,400 women and girls are employed as stenographers, clerks, telephone girls, teachers and in other capacities in the factories, stores and business offices of Sioux City." These young women did not consider marriage, the report continued, because they "say that they must work to make their own livelihoods." At the same time, young men said they did not marry "because the girls work so cheaply that wages have been reduced until their meagerness is not sufficient for two to live upon." Even with a 22 percent increase in the number of business establishments in Sioux City between 1904 and 1909, the situation deteriorated further as the number of females seeking jobs also increased; in the same years the number of wage earners jumped 61 percent. Abstract of the Census of Manufactures, 1919 (Washington, DC, 1923), 303. Susan Brownmiller, "Speaking Out on Prostitution," Notes from the Third Year: Women's Liberation (New York, 1971), $37-39,441-43$, debunks the widely held idea that prostitution is a "victimless crime." See also Gerda Lerner, The Female Experience: An American Documentary (Indianapolis, 1977); Lubove, The Progressives, 317; and Rosen, Lost Sisterhood, chap. 8. 
Copyright of Annals of Iowa is the property of State of Iowa, by \& through the State Historical Society of Iowa and its content may not be copied or emailed to multiple sites or posted to a listserv without the copyright holder's express written permission. However, users may print, download, or email articles for individual use. 